\title{
Geodynamic features of the Black Sea-South Caspian megadepression evolution in the Meso- Cenozoic time
}

\author{
E. Yu. Pogorelova* \\ Azerbaijan State Oil and Industry University, AZ1010, Azadliq ave.,20, Baku, Azerbaijan
}

\begin{abstract}
The Black Sea-South Caspian megadepression is a vast region includes large geological structures developed during the Meso-Cenozoic time and have both a single development history and a different one. Based on the chemistry of volcanic rocks and seismic data, to determine the genesis of the geological structures that make up the Black Sea-South Caspian megadepression, its evolution and the presence of minerals an attempt was made. Large modern geostructural elements, such as the Riony, Kura, West Turkmenian, Black Sea and South Caspian depressions, which are part of the megadepression, have united into a single whole as a result of processes taking place on the margin Tethys Ocean. Based on the analysis of volcanic rocks buried under Cenozoic sediments, the picture of the ancient ocean margin development and its subsequent history were modeled. Favorable conditions for the generation and accumulation of hydrocarbons, formed as a result of all processes, led to the fact the entire Black Sea-South Caspian megadepression has a huge reserve of these minerals.
\end{abstract}

\section{Materials and methods}

To achieve this goal, the author used the method of analyzing volcanic rocks and seismic wave velocities when determining the age and belonging of a particular geological structure of the study area to the elements of geodynamics. Ultimately, the identification of potential places of hydrocarbon accumulations in the Black Sea-South Caspian megadepression based on the geodynamic analysis development of the territory.

\section{Results and discussion}

The methods used made it possible to determine, firstly, the geodynamic development of such large elements of the Black Sea-South Caspian megadepression as the Colchis, Kura and West Turkmenian depressions, and secondly, by the petrological composition, determine the presence of volcanic arcs remnants or rifts in their geological cross-section.

\footnotetext{
*Corresponding author: yy_pgrlova@mail.ru
} 


\section{Scientific novelty}

The presented studies showed, since this territory was an active continental margin in the Mesozoic and was in crustal compression conditions, where horizontal movements were transformed into vertical and fold-forming, then all anticlinal structures formed before the start of hydrocarbon migration can be potentially oil and gas bearing, i.e. Upper Cretaceous-Cenozoic deposits in the Kura and South Caspian depression with a favorable lithological composition.

In the Colchis hollow, due to rifting took place in the Late Jurassic and Late Cretaceous, the Early Cretaceous and Paleogene-Miocene sediments can be as oil and gas sources.

\section{Practical significance}

Analysis of the depression zone development of the Black Sea-South Caspian megahollow, designation of individual geostructural elements as geodynamic units with which minerals are a priori associated, allows us to identify new locations of hydrocarbons.

The Black Sea-South Caspian megadepression is represented by the Black Sea and South Caspian basins and the Riony (Colchis), Kura and West Turkmenian depressions (Figure 1).

The territory in the Mesozoic was an active continental margin of Eurasia (island arc, marginal sea of the southern slope of the Greater Caucasus) and was under compression associated with the approach of Gondwana to Eurasia is considered [1]. It is this system is the island arc (Knipper, 1979). V.E. Khain (1983) mentioned a wide manifestation of vertical movements in the zone of plate convergence.

The study area is a zone of convergence of the Eurasian and Arabian plates, in which the transformation of horizontal movements into vertical ones took place, expressed in the differentiated movement of blocks, the development of uplifts and troughs, limited by deep faults, which sometimes had the character of seismic focal zones, in the inversion of uplifts and troughs, in the change of positive and negative movements along the faults.

Within the Kura depression, the Mesozoic stratigraphic section is represented by the formations of two island arcs - the lower and upper, and in the Colchis depression there is only one island arc - the lower.

The cross-section of the lower island arc corresponds to the Bajocian and is associated with the ensimatic island arc, which was formed within the central part of the Kura depression due to the closure of the Paleo-Tethis relic within its limits. The section of the upper island arc corresponds to the Late Jurassic - Late Cretaceous time and associated with the subduction of the Meso-Thetis Ocean Bay in the Sevan (Goycha) -Akera zone. Indeed, if under the dacites, andesite-dacites of the Upper Bajocian, neutral-composition rocks andesites, andesite-basalts of the calc-alkaline series are exposed ( which is very likely) since this is the section that is characteristic of the Samkhety-Agdam zone of the Lesser Caucasus (they show a certain similarity volcanic rocks of the Kurdamir-Saatly uplift), and tholeiites of an island arc with a simatic base will lie beneath them, this will be a section of a mature island arc that has gone through the entire cycle of its development [2]. It is similar to the cross-section of the Tonga-Kermadec oceanic arc (Brian, 1983), where dacites occur at the top. 


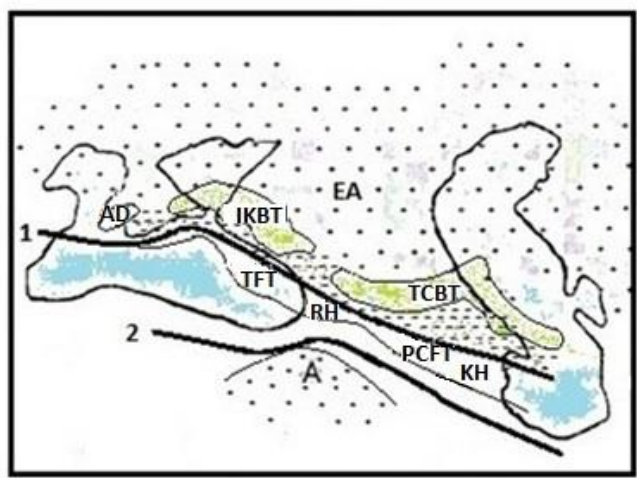

composed by E.Yu Pogorelova, 2019

\author{
EA-Eurasian plate \\ A- Arabian plate \\ IKBT - Indol-Kuban back trough \\ AD - Almin depression \\ TCBT -Ter-Caspian back trough \\ TFT - Tuapse foredeep trough \\ PCFT-Pre-Caucasian foredeep \\ trough \\ KH-Kura hollow \\ RH-Riony hollow \\ 1. Crimean-Caucasian \\ paleosubduction belt \\ 2- Anatolian-Pontidian- \\ Lesser Caucasian- \\ Albourz ophiolite belt \\ - Crimean-Caucasian \\ folded region
}

Fig. 1. Geodynamic model of the Black Sea-South Caspian megadepression

The next island arc cycle is the Late Jurassic-Late Cretaceous, and the Upper JurassicLower Senonian volcanic rocks belong to the calc-alkaline series (the Upper JurassicNeocomian - Saatly, Neocomian - Jarly, Aptian-Santonian - Muradkhanly, Upper Senonian - Muradkhanly) in composition they correspond to shoshonite - volcanic rocks, characterizing the mature stage of the ensimatic island arc (Dmitriev and Tsvetkov, 1983; Miashiro, 1974). The homodromic character of the upper island arc section is emphasized by the intrusions represented by quartz syenite-diorite and granit-diorite, exposed by wells No. 1 and 3 of the Karajaly area within the Kurdamir-Saatly buried uplift and emphasizing the maturity of the island arc [3]. The radiometric age of quartz syenite-diorite is 90 million years. Both island arc cycles emphasize the incompleteness of the continental crust development and the absence of a final continental stage. A similar analogy is known for the Ural mountains (Berlyand, 1981).

In the Colchis depression, in the Mesozoic, one cycle appeared - the BajosianBathonian, also with the character of volcanism $[4,5]$ of the homodromic type, but here the development cycle is complete, since its final, continental stage, which is associated with the build-up of the granite layer (Bathonian orophase, granitoid magmatism, molasse).

Within the ensialic blocks on the Kura depression territory, the "granite" layer is represented by Middle Jurassic volcanic rocks and formations of the pre-Jurassic basement. Within the ensimatic block, the "granite" layer corresponds to the Middle Jurassic volcanic rocks, and the formations of the pre-Jurassic "granite" layer are absent. I.e., where the earth's crust has a reduced "granite" layer (in the case of an ensimatic block), the process of oceanic crust transformation into a continental one stopped at the island-arc stage (the central part of the Kura depression).

Within the Colchis depression, the "granite" layer is expressed by the pre-Jurassic basement, since the Middle Jurassic volcanic rocks [6] have a lower density and velocity than those of the Kura depression. In the Colchis Basin, this is due to the rifting that took place here in the Late Jurassic and Late Cretaceous, which led to the decompaction of Middle Jurassic volcanic rocks during extension.

Within the ensialic Vandam block, the velocity and density characteristic of the "granite" layer are associated with volcanic rocks of Middle Jurassic [1].

Drilling carried out by the Saatly superdeep well, correlated with data (deep seismic sounding) and (correlation method of refracted waves), also shows the confinement of the surface with $\mathrm{V}=6.5 \mathrm{~km} / \mathrm{s}$ to the Middle Jurassic volcanic rocks. Within the ensimatic block, the analysis of the (correlation method of refracted waves) and (deep seismic sounding) data shows that the thickness of the formations corresponding to the Jurassic 
deposits within the Kurdamir-Saatly uplift is more than $5 \mathrm{~km}$. It increases in the direction of the Yevlakh-Agjabedy trough [7].

In this case, the rock stratum with the specified velocity lies on the formations to which the velocity $\mathrm{V}=6.7-7.0 \mathrm{~km} / \mathrm{s}$ is confined, that corresponds to the surface of the basalt layer. But within the ensialic blocks, as indicated above, the thickness of the layer sharply rises, to which the parameters characteristic of the geophysical "granite" layer are confined. This can be seen on the (deep seismic sounding) profile No. 1 along the AgjabedyByandovan line as interpreted by B.D. Trebukova, on which, to the east of the West Caspian fault, within the Lower Kura depression, the thickness of the "granite" layer jumps up to $12 \mathrm{~km}$, against $4 \mathrm{~km}$ in the area Saatly, where, as mentioned above, the Lower-Middle Jurassic formations are corresponded to it.

The same situation is observed on the profile No. 9 of the (deep seismic sounding) in the interpretation of K.M.Kerimov (1975), which was also worked out along the line of Agjabedy-Byandovan. On the gravimetric profile along the Anaklia-Karshi line, interpreted by B.K. Balavadze and G.K. Tvaltvadze (1960), it can be seen how the thickness of the "granite" layer sharply increases to the north of the Mingachevir-Goychay deep fault. The tectonic nature of this phenomenon is as follows: there is no granite-metamorphic substrate within the ensimatic block, since an island arc existed here, which was formed on the ensimatic foundation, and the process of continental crust formation did not go beyond the island arc - intermediate stage. In the case of the ensialic blocks, these are segments of the island arc, which was formed on the ensialic base. Naturally, within the ensialic blocks, the "granite" layer is composed of the island-arc complex of the Jurassic age and the formation of the pre-Jurassic crystalline basement, which explains the increased thickness of the "granite" layer compared to the ensimatic block.

The velocity $\mathrm{V}=5.2 \mathrm{~km} / \mathrm{s}$ for the Kura depression is defined as the boundary between the Upper and Lower Cretaceous.

Within the eastern part of the West Turkmenian depression [8], the basement surface is confined, possibly, to the upper Paleozoic, but rather the Triassic (Early Cimmerian folding, and in the western (coastal) part, likelihood, the "granite" layer is represented by island-arc formations of the middle Paleozoic, those are characteristic of the Turan plate.

\section{Results and discussions}

Analysis of geophysical materials led to the conclusion, differences in the history of the Kura and Colchis depressions development predetermine the confinement of velocities and densities taken for the basement surface to different historical boundaries [9]. The data of Georgian geophysicists (Ioseliani, 1969, 1982; Marusidze, 1976; Shengelaya, 1968; Tvaltvadze et al., 1973) show, in Georgia the values of velocities and densities characteristic of the geophysical "granite" layer correspond not to Middle Jurassic volcanic rocks, but to pre-Jurassic formations. The data of M.S. Ioseliani (1982) show, the volcanic rocks of the Middle Jurassic of Georgia are less dense than those in Azerbaijan. It should be borne in mind here the Middle Jurassic is absent in the Adjarya-Trialetiya and on its eastern continuation - in the pre-Tbilisi region, in the Artvin-Bolnisi zone; it is eroded in the northern part of the Alazani depression. In this case, the geophysical "granite" layer corresponds to the pre-Jurassic basement. Concerning the Colchis hollow, the lower density of its Middle Jurassic volcanic rocks [5] is due to the fact the Middle Jurassic volcanic rocks within its boundaries twice - in the Late Jurassic and Late Cretaceous - experienced the influence of deconsolidating factors associated with the rifting process at the indicated time. The Middle Jurassic volcanic rocks of the Kura depression continued to be in islandarc conditions throughout practically the entire post-Jurassic interval of the Mesozoic 
compression, which undoubtedly contributed to the preservation of the level of its physical properties.

As a result of the research, it was possible to generalize and analyze the large volume geological and geophysical material, which formed the basis for the study of the Phanerozoic development of the South Caspian-Black Sea region. Such an opportunity appeared due to the use of the paleotectonic analysis method, carrying out palinspastic reconstructions, using data from volcanology. A model for the emergence of subcontinental crust segments within the oceanic space of Prototethys and its further evolution in the inherited developing ocean of the Paleotethis is proposed. In the South Caspian segment of the territory under consideration, up to the Bathonian, there was a relict Paleotethis zone, which to the east up to the present is characterized by the subcontinental and suboceanic crust of the central part of the Kura depression and the South Caspian basin. Much attention in the process of research was paid to the relationship of constructive and destructive processes taking place in the region [10]. And, if the primacy of the constructive process is characteristic of the South Caspian segment, then in the Black Sea segment these processes shifted each other in time, creating conditions for both the formation of the continental crust and its destruction. In the process of research, it was possible to identify zones of an unfinished developmental cycle, inherited by sagging during the Meso-Cenozoic, as well as zones formed on the oceanic basement (ensimatic island arcs with subsequent generation into the molasse trough).

\section{Conclusions}

The studied area in the Mesozoic was an active continental margin of the Pacific type, being a transitional zone from continent to ocean. Within the island arc that existed in the Mesozoic, it was possible to distinguish its segments formed on the oceanic crust and on the continental crust. This circumstance suggests that with the features of an active continental margin of the Pacific type, features of an active continental margin of the Antillean type are manifested here.

An important aspect of the studies carried out is the identification of such elements as the molasse, but unimposed trough (most of the Kura depression) and the epirift molasse trough (the present-day deep-water part of the Black Sea depression).

It is the constantly sagged areas during the Mesozoic or in the Late Mesozoic and Cenozoic are promising for oil and gas content (Absheron Peninsula, Lower and Middle Kura depressions, West Turkmenian depression). In this case the folding should be of an intermittent type, i.e. undisturbed by orogenesis - a destructive process in relation to it.

Zones of inherited subsidence can be promising due to oil and gas content, since they developed continuously. Such zones are the Absheron Peninsula, the Lower Kura depression, the Shiraky-Ajinour zone.

In the West Turkmenian depression, the structural plan changed in the Paleogene. The modern structural plan within it has been formed since the Pliocene. Oil and gas potential, both discovered and prospective, is associated with Paleogene ("subred-colored") terrigenous and Neogene-Quaternary sediments.

The water areas of the South Caspian and the Black Sea, with the most improving methods of geophysics, will predetermine researchers for many years to a multivariate solution to the problems associated with those, creating a wide range of debatable issues. 


\section{References}

1. P. Mamedov, Petroleum geology and hydrocarbon potential of the Black and Caspian seas region. Baku. Azerbaijan (2002)

2. E. Yu. Pogorelova, Geological structure and development of the Pre-Lesser Caucasian trough and the prospects for the oil and gas content of the Upper Cretaceous deposits, 148 (1991)

3. E. Yu. Pogorelova, Third International Conference on Geology of the Caspian Sea and Adjacent Areas, 5 (2019)

4. The Greater Caucasus in the Alpine era. Moscow. GEOS, 382 (2007)

5. Ye. Yu. Pogorelova, Scientific Bulletin. NHU, 1, 5 (2019)

6. A. V. Harutyunyan, Bulletin ONZ RAN, 2, 44 (2010)

7. R. R. Rakhmanov, Regularities of the formation and placement of oil and gas deposits in the Meso-Cenozoic sediments of the Yevlakh-Agjabedy trough, Baku, 191 (2007)

8. I. S. Guliev, D. L. Fedorov, S. I. Kulakov, Oil and gas potential of the Caspian region. Baku, 409 (2009)

9. M. L. Somin, Report at the Belousov readings, Moscow: IPE RAS (2005)

10. A. A. Alizade, I. S. Guliyev, P. Z. Mamedov, E. G. Aliyeva, A. A. Feyzullaev, D. A. Huseynov, Productive strata of Azerbaijan, 1, 305 (2018) 